\title{
Preparing English Department Students for Industry 4.0 Era through Critical Thinking Skills Development
}

\author{
Rolisda Yosintha ${ }^{1}$, Taufik Arochman ${ }^{2}$ \\ \{rolisda@untidar.ac.id ${ }^{1}, \underline{\text { taufik_arochman@untidar.ac.id }}{ }^{2}$ \} \\ ${ }^{1,2}$ Faculty of Education and Teacher Training, Universitas Tidar, Indonesia
}

\begin{abstract}
The purpose of this review is to shed light on how to build critical thinking skills as one of the necessary skills that all students in higher education level need to be able to compete in the Industry 4.0 era. To ensure success, the worldwide industries in the fourth industrial revolution require their workforce to have not only technical skills but also soft skills, particularly critical thinking skills. With this new trend, English Department students are challenged to develop their critical thinking skills to supplement their English competences to be able to meet the ever-growing needs of the industry. Through a study of literature, this paper proposes some instructional strategies that the English Department could implement to build the students critical thinking skills and ultimately create a workforce ready for the tough competition in the Industry 4.0 environment.
\end{abstract}

Keywords: critical thinking skills, industry 4.0, English Department students

\section{INTRODUCTION}

The fourth industrial revolution, popularly known as Industry 4.0, has transformed our workforce to be more competitive and capable of quickly adapting to technological development. All organizations and institutions are forced to use advanced technologies to survive in this Industry 4.0 competition. However, being able to tailor the industry to these developments alone is not enough. Nowadays, more and more industry demand that its workforce has more than just technical skills. Soft skills, particularly critical thinking skills, are increasingly counted as essential aspects to be considered when recruiting employees since by investing in agile and adaptable employees with high critical thinking industry can ensure success in the long run.

Deloitte Global's 2018 Millennial Survey reveals that high innovators look for three primary top skills in their employees to keep up with the growth of Industry 4.0: critical thinking skills (46\%), cybersecurity, privacy, and compliance awareness (43\%), and in-depth knowledge and expertise of Industry 4.0 technologies (43\%) [1]. This new drive in critical thinking development to meet the demand of Industry 4.0 automatically leads to a significant change in all aspects of life, including education. Higher education institutions are urged to change their curriculum to suit the characteristics of Industry 4.0 era. Only by doing so will it be possible for their graduates to be able to present the right skills required by Industry 4.0 and ultimately win the competition.

To think critically means to examine ideas and presumptions rather than take them for granted without analyzing first. A critical thinker must be able to use their ability to reason, analyze, and solve problems systematically before believing something to be true or false based 
on their judgment. In essence, critical thinking might be described as the ability to think clearly and rationally about a situation or problem and find the most effective solutions for it. Having this trait, one can decide what he/she aims to achieve and make the right decision on how to reach that aim after considering a range of as many different sources as possible. Such trait is fundamental for students to possess for they are the next generation that will have a tougher fight to compete in Industry 4.0. Without it, they will not be able to fit in the expected work environment, and thus, they will be left behind and lose their chances.

When the urge to engage in critical thinking skills is getting higher and higher, it is regrettable that many of our students lack this essential skill. In a study on East Asian Master's students' critical thinking skills, [2] notices that these students tend to be passive recipients of the information. Even though the lecturer has presented the materials in such a way that encourage debate or discussion, these students rarely disagree with what the lecturer opines. Further, a study carried out by [3] has proved that there is an alarming deficiency of critical thinking skills among college students, as indicated in the nowadays industry leadership. With the limited number of critical thinkers available in the labor market, it is getting harder for the industry to have effective leaders. To avoid any further detrimental effects of this deficiency, students must be equipped with abundant knowledge and experience in critical thinking skills, leading to an excellent opportunity for better career development in the future.

To be able to compete more broadly in the industry, surely students need another means other than their technical competences as supported by their soft skills, i.e., English language. Having a mastery of this lingua franca, students will have a broader opportunity to choose their career path and succeed in life. As for English Department students, it is expected that they can benefit significantly from the English competences they have developed during their study, and thus lessen their burden in this Industry 4.0 competition. It must be kept in mind, however, that having English competences alone is not enough. This technical skill must be supported by a range of soft skills, especially critical thinking skills so that later they can adapt to the development of the industrial revolution and strive for better career growth.

A plethora of studies have investigated English Department students' critical thinking skills in various aspects. In a study concerning Arab EFL students' performance in their Writing class, it was found out that these students failed to produce satisfactory writing not because they lacked linguistic competences such as grammatical and vocabulary items, but because they did not think critically in developing their ideas [4]. This condition is worsening as not only do the students show inadequate critical thinking skills, but the lecturers themselves may also not know how to incorporate this skill into the teaching and learning process [5]. This condition suggests that critical thinking skills are minimally practiced among students and lecturers, including those in the English Department.

Considering the importance of critical thinking skills in determining success in a future career, fostering critical thinking skills among English Department students should be facilitated in such a way that all students can maximize their potential. This issue has interested the authors in examining any possible measures to prepare English Department students for the Industrial Revolution 4.0 era through critical thinking development. To facilitate the flow of the discussion, this study focuses on the following research questions:

1. How are critical thinking skills related to Industry 4.0?

2. How is the application of critical thinking skills in higher education?

3. How is the critical thinking skill of English Department students?

4. How can critical thinking skills be developed in English language teaching context? 


\section{METHOD}

The current research is a library study which attempts to present, explore, and elaborate the current issues on the development of students' critical thinking skills, especially the English Department students, in relation to the impact of industrial revolution 4.0 on education.

This review will not only explore what critical thinking is but also scrutinize its characteristics and components that force English Department students to develop their ability in critical thinking in relation to the growing demand of Industry 4.0. After discussing the benefit that English Department students can get from critical thinking skills, this review will propose some measures that English Department stakeholders can take to build the students critical thinking skills, primarily through the teaching and learning process. In the end, English Department students are expected to be able to implement these critical thinking skills for solving problems effectively in their future workplace.

\section{FINDINGS AND DISCUSSION}

In response to the challenges faced by the world of education in the Industry 4.0 era, the most important thing is to create graduates fully equipped with all competencies required by the ever-growing revolution. To be able to meet such an expectation, it is urgently needed that students be exposed to a plethora of learning experiences that not only help them grasp the field-related knowledge effectively but also stimulate the development of critical thinking skills.

\section{Critical Thinking Skills in Industry 4.0}

Industry 4.0 is the fourth industrial revolution that shifts the ways industry carries out its production and operation system. In this era, the use of computers in the industry which was initially introduced in the Industry 3.0 is now further developed through interconnectivity, making it possible for those computers to share information and ultimately perform a decisionmaking action without human involvement.

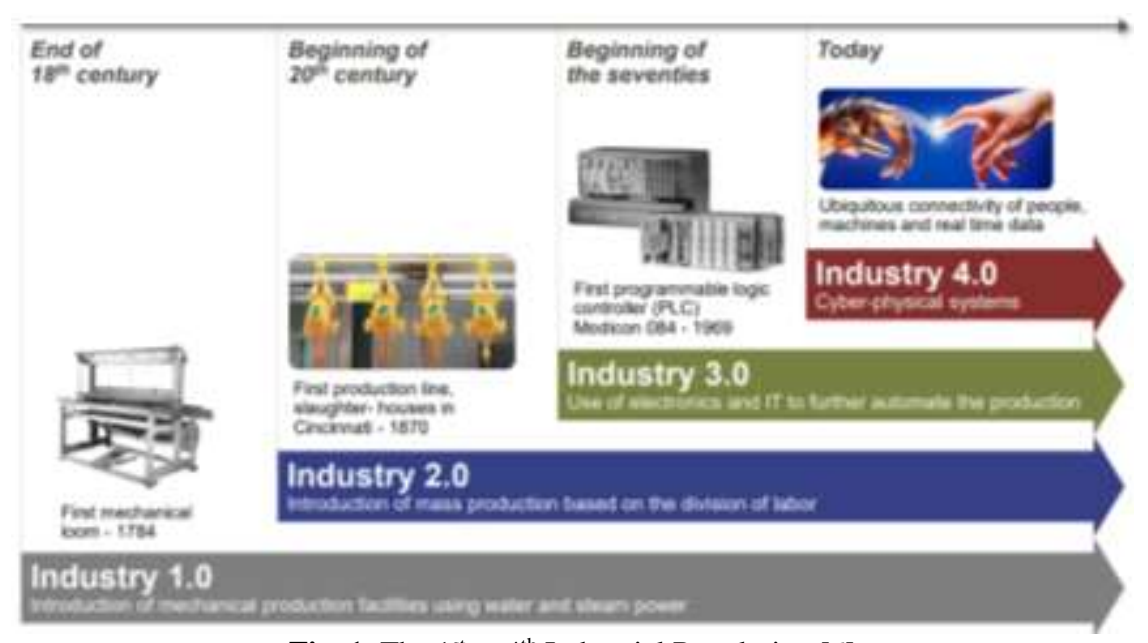

Fig. 1. The $1^{\text {st }}$ to $4^{\text {th }}$ Industrial Revolution [6] 
This new era focuses on the concepts and technologies that involve cyber-physical systems, the Internet of Things, and the Internet of Services [7] [8]. As the name suggests, cyber-physical systems integrate both cyber and physical processes in the industry. In this system, computers and networks monitor and control the physical processes, and the system will get feedback to be then processed in the computation system all over again. The Internet of Things (IoT) refers to a network of physical objects connected through the Internet so that they can gather and share electronic information. Meanwhile, the Internet of Services implies that everything developed using software applications is available as a service on the Internet.

With the widely available data, borderless connection, and vast opportunities offered by Industry 4.0, many challenges arise in all fields, including in education. Education institutions should adapt to the demands of Industry 4.0 and create adequate contexts for the students to be prepared for the enormous challenge of their future jobs. Students need to know how they can make a correlation and apply their knowledge of various sources and contexts by integrating technologies in the process. In addition, these education institutions should train their students not only with the how-to benefit from the technologies but also with the values associated with the use of these technologies. In other words, industry 4.0 requires a workforce that not only can adapt to the never-ending technological development but also possess new skill sets to tackle the problems engendered by this development. Therefore, it is imperative that students be prepared and trained to be critical thinkers to be able to cope with the complex situations that may come up in the future workplace.

Critical thinking is not a new theory or practice. In fact, this concept has been around and practiced since many centuries ago by Socrates. His Socratic method, widely known as Socratic Questioning, puts emphasis on the process of internalization to facilitate the formation of critical thinkers [9] [10]. When learning using this method, students are always encouraged to question and discuss ideas to analyze the accuracy, clarity, relevance, depth, and breadth of the reasoning. Through questioning, students will come up with more profound thought, resulting in a higher level of understanding.

In its development, critical thinking is defined and interpreted in many ways through various perspectives by experts and scholars. Paul [11, p. 28] defines critical thinking as "the art of thinking about thinking in an intellectually disciplined manner." In this definition, what is meant by critical thinking implies more than just giving thought to something as it involves analyzing, assessing, and improving thinking. This notion is further strengthened by [12], stating that critical thinking encompasses not only some dispositions including attitudes, habits of mind, and attributes, but also cognitive skills such as abilities to interpret, analyze, and finally evaluate.

Ennis as cited in [13], provides a more thorough description of what critical thinking is by mentioning not only cognitive but also disposition (i.e., mental states that affect feelings, volition, and behaviors) aspects in his elaboration. For him, a critical thinker is someone who holds a view, defends it, or change it based on evidence and arguments. He/she should understand the causes of problems and look for a solution to overcome the issues effectively. In addition, values such as open-mindedness, empathy, and integrity should also be present in a critical thinker's personality traits.

The above definitions of critical thinking lead to some common aspects of this trait that are needed by the Industry 4.0 environment. First, critical thinking encompasses a set of cognitive skills such as abilities in analyzing, interpreting, augmenting, evaluating, inferring, proposing, creating, and making decisions based on relevant and reliable information. Second, a critical thinker should possess values related to this trait, namely humility, integrity, prudence, empathy, etc. 


\section{Critical Thinking Skills in Higher Education}

Concern about the urge to facilitate students in developing their critical thinking skills has increased more than ever because of the more complex demand of labor market in the Industry 4.0 era, which is characterized by rapid changes and advances in both technology and knowledge. In other words, it is highly recommended that critical thinking be adopted in education with respect to students' autonomy in learning and the efforts to prepare them for success in both academic and career life. This is in line with the statement of [14] that the development of critical thinking skills should be the primary objective of education.

Even though critical thinking skills are often regarded as something born [15], [16] [17] believe the opposite, i.e., critical thinking skills are not a fixed entity. Instead, they assert that these skills are a form of intelligence that can be learned. It is gradually acquired through the teaching and learning process as it develops at the same time with the development of cognitive skills. This process takes place when students are provided with ample resources that require them to give reflexive and efficient answers to particular circumstances.

As it is clear that critical thinking skills can be learned, it is now a matter of where students can learn these skills. In the basis that critical thinking skills are highly associated with the demands of the labor market, it can be suggested that higher education institutions have a more significant part of this responsibility for providing students with ample opportunities to develop these skills since their graduates are the future workforce in various fields. It is in higher education that students learn what they need to know to be able to meet the standard of future employment trend in terms of not only the field-based competencies but also the critical natured thinking skills [18] [19] [20]. Students should develop their capacities to think critically, understand oneself critically, and finally act critically.

Despite the importance of these skills for students, practical efforts to instill such skills in students' competencies have not been noticeable so far [2] [3] [19]. In fact, most students learn through conventional teaching methods and are assessed conventionally as well through tests on data transmission and memorization of concepts and information [11] [21]. It is also a common practice that students are passive recipients of knowledge offered by the teachers. Teachers are often regarded as experts who know everything about the subject matters, and their primary duty is to transfer all knowledge they have to the students. On the other hand, the students are there to listen to the teachers, take notes, memorize things, and do the tests. They will then be assessed based on what they have memorized from the lesson, not from their own ideas and reasoning. As the results of this passiveness and dependence on teachers, these students cannot maximize their potential to elaborate ideas on their own, and ultimately fail to develop the skills they need to solve their problems automatically.

These problems inevitably draw attention from educators and policymakers in a higher education environment. Thus, a lot of institutions strive for a better reference to standards and parameters related to the implementations of critical thinking skills development. For example, the Australian Higher Education Council explicitly stipulates in its educational policy that all graduates from any study programs must develop and demonstrate competences in thinking critically, solving problems, selecting and managing information, being intellectually curious and rigor, showing ethical values, integrity, and tolerance, etc. [22]. In the same line, the Colombian National Ministry of Education reforms their previous curriculum to include critical thinking, analytical and synthetic reasoning, and creative thinking as some of the generic skills compulsory for all higher education graduates [12].

Even when the curriculum has already stipulated the integration of critical thinking skills into the teaching and learning process, Astleitner, as cited in [18], asserted that the development of these skills is not yet maximum for they are not systematically taught in the 
daily instructions. Furthermore, teachers/lecturers are too busy to find other instructional resources to integrate these skills. Therefore, it cannot be denied that these teachers need a professional development model to learn how to teach and infuse critical thinking skills at the same time.

In Indonesia, the importance of critical thinking skills has already been explicitly mentioned in the regulation of the Minister of Research, Technology, and Higher Education Number 44 of 2015 [23], stating that all higher education graduates must meet affective, cognitive, and psychomotor qualifications. For the last one, it is further specified in the act appendix, that college graduates must demonstrate adequate both generic and special skills, and the former one explicitly includes abilities to think logically, critically, innovatively, and in a measurable manner.

Unfortunately, several studies reported unsatisfactory critical thinking skills among Indonesian college students [24] [25]. One of the factors identified as the cause of these problems is the lecturers' perception of the development of their students' critical thinking skills. In their current study, [24] found that out of 48 lecturers spread in four different universities, there were only $32.05 \%$ of them who included critical thinking skill aspect in their evaluation sub-scale. It showed that little emphasis was put on the development of students' critical thinking skills. In addition, only $39.32 \%$ of the lecturers varied the learning models or strategies to stimulate the students' critical thinking skills development. In fact, the learning activities were dominated by lectures $(58.13 \%)$, which principally lead to few opportunities for students to do better in problem-solving, making a decision, and thinking analytically and critically.

As there are a lot of problems concerning the students' critical thinking skills, it is getting more evident that there is something that must be fixed in our education system, especially in higher education contexts. Even though higher education level is not compulsory for students, the needs and awareness of the importance of higher education are growing fast to catch up with the demands of Industry 4.0. This institution is expected to be able to create graduates with the attributes of a critical thinker who later will be the workforce in Industry 4.0. They must show open-mindedness, pursue truth actively, demonstrate excellent communication skills, accept criticism, perform self-reflection, etc. Having all those traits, they will be able to solve problems in the future workplace, take careful decisions, create innovations, and finally benefit their institutions.

\section{The Critical Thinking Skills of English Department Students}

Just like other students, English Department students must work hard to compete for jobs in the Industry 4.0 competition. Given the increasingly complex competencies needed in this era, students cannot rely solely on their field competencies. To support career development and industry expansion throughout the world, indeed they must have adequate communication skills. This is why English language skills are essential for all college graduates. English Department graduates may feel a little at ease because they are already equipped with competence in the field of English, but in reality, many non-English Department students can speak English well, even better than English Department students. This irony raises concerns for graduates of the English Department because their chances of getting a better job may be smaller because they are rivaled by non-English Department graduates. Therefore, English Department students must supplement their field competencies with soft skills that not everyone can have it, and one of them is critical thinking skills. With adequate critical thinking skills, the English Department graduates can be superior because, in addition to having 
excellent English skills, they are also able to think critically in solving problems in the world of work which will undoubtedly become increasingly complex over time.

Despite the importance of critical thinking skills for English Department students and students learning English as a second or foreign language in general, several studies suggest that their critical thinking skills are not yet satisfactory [4] [26] [27] as proved by their performance in the class. They might score well in the exam but fail in employing critical thinking skills to solve their daily problems. In a study carried out in an EFL writing class in China, [27] found out that students' low achievement in writing was due to the inadequate exposure to activities which develop critical thinking skills. Critical thinking skills are often ignored in the writing process for the learning process is focused more on grammar and structure materials, causing the students to have little chances to develop effective essays.

Lecturers may also bring about constraints in the development of students' critical thinking skills in higher education. In a study in English as a Foreign Language (EFL) contexts, [12] argue that these constraints are due to the lecturers' lack of knowledge about the nature of critical thinking skills and the ways to develop it. In addition, obstacles in implementing these skills may also derive from the curriculum. Lack of instructions and the perpetuation of traditional teaching model as defined in the curriculum leads to unbeneficial restrictions that hinder lecturers' creativity in stimulating the students' critical thinking skills.

Several studies have also been carried out in the Indonesian context concerning the critical thinking skills of English Department students [28] [29]. A study aimed at determining the level of critical thinking skills of 31 third-year English students in one of the public universities in Java proved that when compared to the critical thinking skills level of American secondary school and university students, that of Indonesian students was lower in all sub-scales [28]. Another study tried to correlate the degree of Indonesian students' critical thinking skills with cultural and family backgrounds as well as learning strategies and found that these factors do not play a significant role in the development of English Department students in one of the state universities in East Java [29].

It appears that the development of English Department students' critical thinking skills is not only affected by external factors such as teaching method, exposures, assessment form, etc. A study carried out by [26] on the critical thinking skills of 2,875 students learning English as a second language showed that interest in learning English plays a vital role in determining the students' success in developing their critical thinking skills. Students with interest in learning English have higher critical thinking skill level compared to those having little or no interest in learning English. Furthermore, they found that female students are proved to have a higher critical thinking skill level than male students, implying that female students' higher interest in learning English is due to their higher critical thinking skills.

In another study, it was found that not only the interest factor that plays a role in determining the success of the students' critical thinking skills development. Through some reflection activities among 55 English Department students in Yogyakarta, it was found that students' unsatisfactory critical thinking skills were also affected by several internal factors such as inability to maintain their concentration during reading activities, lack of interest in the topic, insufficient knowledge of the topic, reluctance to criticize, laziness, and the level of the text difficulty [25]. To tackle these constraints, they asserted that they need a learning environment in which they can intensively nurture their critical thinking skills.

Based on the elaboration above, the writer can conclude that the gap between the complex problems that the students of English Department might encounter in their future workplace and their current critical thinking skills may arise from several factors. First, their critical thinking skills have not met the desired outcome as affected by some external factors such as 
teaching materials, exam-oriented learning, and teacher-centeredness. Teachers/lecturers tend to pay more attention to the teaching of technical aspects such as grammar, reading, and writing skills. They put communicative elements in second place in their teaching. The teaching methods they use are usually teacher-centered, and thus hinder the development of students' critical thinking skills. In addition, the students are often drilled with exercises in an effort to pass the exam. These methods surely discourage students from activating and practicing their critical thinking skills, which are essential for developing better learning. Second, no matter how supporting the external factors are, without internal motivation and interest, the students would find it difficult to develop their critical thinking skills. Many students have no clue of what critical thinking is, and they do not know the importance of these skills for their future, leading to the situation in which they do not make any necessary efforts in learning to develop these skills.

\section{Building Critical Thinking Skills in English Department Context}

Critical thinking is highly related to quality thinking. It is agreed that when this skill is well developed, it will be easier for students to acquire new knowledge, deal with ideas, solve problems, and communicate with others. However, in real practice in EFL or ESL classroom setting, there is often a separate process intended to learn the language and think critically [30]. In other words, there is little integration between language and thinking skills. Even in a communicative language teaching in which the use of language as a communication tool is emphasized, students often fail to be proficient in the target language [30]. It is argued that students must think critically and creatively to be able to be proficient in a language, and ultimately gain success in Industry 4.0.

Due to the significance of improving critical thinking in language students, especially English Department students, the teaching and learning objectives in this context must go beyond linguistic competences. Lecturers must facilitate the development of critical thinking skills, while the students are learning the target language. There are plenty of instructional strategies to incorporate critical thinking skills into the teaching and learning process in the English Department context as the followings:

\section{Giving explicit instruction}

To integrate critical thinking skills into the teaching and learning process, it is suggested that lecturers employ explicit instruction rather than the implicit one. In this explicit approach, critical thinking principles are taught directly by making the expected skills clear to the students. Meanwhile, the implicit approach does not introduce critical thinking skills distinctly for these skills are expected to develop naturally at the same time with the students' understanding of the subject matter. In other words, since critical thinking skills are not automatically acquired as the by-product of studying certain subject matters, explicit instructions are indeed needed to prepare students to become critical thinkers, and thus these skills should be practiced intentionally and taught explicitly as an integral part of the curriculum.

The preference for explicit instruction to boost critical thinking skills has been affirmed by some researchers. Explicit teaching is proved to have more substantial effects on the development of the expected critical thinking skills when compared to the implicit one [31], and the direct teaching of a specific critical thinking skill such as argument analysis could significantly enhance the critical thinking performance and metacognition among college students [32]. In addition, this approach is particularly indispensable for students with a non- 
western cultural background as they often lack practice and experience in critical thinking skills [33].

In English Department context, lecturers are required to not only understand how critical thinking can be related to language learning, but also be capable of explaining, modeling, and infusing the concepts of critical thinking into their instructional designs and learning activities. For reading instruction, for instance, lecturers can explicitly teach critical thinking skills related to reading by explaining, modeling, and practicing. These skills include analytical skills (identifying main ideas, analyzing reasons, identifying writing techniques), inferential skills (predicting, determining the author's purpose and tone, drawing conclusions, interpreting figurative expressions), and evaluative skills (distinguishing facts from opinions, commenting, debating arguments, proving evidence). Through these instructions, the students are expected to be better critical thinkers with such traits as being open-minded and flexible in responding to different views and being able to prevent subjective opinions from interfering with the text understanding.

\section{Questioning}

Asking questions serves many purposes for lecturers, including to increase interest and motivation, to involve the students in the learning process, to review previous lessons, to give insights, to develop critical thinking skills, etc. Concerning the development of critical thinking skills, lecturers should ask the students questions that belong to the higher-level questions, i.e., questions that require more than memorization and factual recall and push the students to make more inference, analysis, and evaluation. This type of questions provides the students with a more significant opportunity to think independently and critically. The higher the level of the questions is, the higher the students' level of responses will be.

In terms of the question forms, it is suggested that lecturers develop open questions rather than the closed ones. Compared to closed questions that often only elicit one or a limited number of possible answers, open questions make it possible for students to explore many acceptable answers, and thus they will have more opportunities to think critically. In addition, referential questions should be preferable than the display ones when aiming at enhancing students' critical thinking skills. When lecturers ask questions that they already know the answers, they employ display question. On the other hand, when they do not know the answers to the questions they ask, they engage students in referential questions that require more complex and more extended responses. These questions may ask for further information, opinion, explanation, or clarification, and thus increase the students' critical thinking skills [34].

In brief, asking higher-level questions in the form of open or referential questions could facilitate students to expand, evaluate, judge ideas, and thus is potentially useful in stimulating students' critical thinking skills.

\section{Adopting Cooperative Learning Strategies}

In developing students' critical thinking skills, it is recommended that lecturers adopt learning strategies that focus on participation, interaction, and cooperation among students. Through such procedures, students would have more opportunities to exchange ideas, engage in productive conversation, defend views, and eventually become critical thinkers. Some of the proposed instructional strategies include role play, group discussion, and debate.

Roleplay is an effective method for stimulating critical thinking skills. Not only will the students enhance their knowledge in a particular area, but they can also apply that knowledge 
in different real-life scenarios through sharing information and negotiating meanings collaboratively. This activity could scaffold the development of students' critical thinking skills through different contexts, and thus helping students to reconstruct their thinking. Similarly, group discussions and debates make it possible for students to exchange information, clarify ideas, express agreement/disagreement, etc. Through thought-provoking topics such as controversial issues, trending topics, current events, and cultural differences, lecturers can hold students' interest longer and thus may get students engaged in the discussion better.

These learning strategies allow students to experience various roles other than their real role in the classroom as students. This new experience they encounter in each practice brings motivation, fun, interest, and a better chance for learning. In the end, the students will grasp the knowledge even better simply because they actively participate in the learning process.

\section{Encouraging Project-Based Learning}

Project-based learning (PBL) is one of the student-centered pedagogies that allow students to gain knowledge through experiential learning. Lecturers function as facilitators making it possible for students to take control and be responsible for their own learning. Through planned projects around topics that allow them to have thoughtful consideration, students can learn to make thoughtful decisions and exercise their reasoned judgments, and thus developing their critical thinking skills [35] [36].

Projects have to be structured with critical thinking as the goal. Models and scaffolds should be provided to help students understand how such tasks are carried out. For example, in a project that requires students to examine the causes of difficulties in writing (poor vocabulary, difficulty with sentence structure and word order, inappropriate use of colloquial language, weak argumentation, unfamiliar topics), weigh their relative importance, and identify the most important cause, the students can have opportunities to brainstorm the causes, form and test some specific hypotheses, have a small group discussion to decide which hypotheses seem more acceptable, construct a well-reasoned argument, and finally present their findings based on the arguments they have agreed upon. When they are directly involved in constructing their own knowledge through experiences, they will find the learning is more meaningful.

\section{Using Criterion-Referenced Testing (CRT) rather than Norm-Referenced Testing (NRT)}

In developing a test for the students, lecturers might come to two kinds of testing systems, namely Criterion-Referenced Testing (CRT) and Norm-Referenced Testing (NRT). While the former measures a student's score against a set of criteria regarding what the students are expected to know and be able to do at a particular phase of their learning, the latter compares and ranks the students in relation to one another. Both approaches have their own strengths and weaknesses.

When it comes to developing critical thinking skills, lecturers should prefer CRT to NRT. In NRT, as the students know that they are going to be compared to the other students, they would feel that they are being pushed to do better than others, and consequently, they tend to learn without thinking about the essence of what they learn and how they will use it. In contrast, CRT embraces differences among students that can be utilized to determine their learning progress, knowing what the students have already known and which ones need to be improved. CRT makes it possible for the students to learn from each other in a non-competitive atmosphere, resulting in an increased focus on understanding than outcomes. With such learning atmosphere, the students would most likely develop their critical thinking skills better. 
To promote critical thinking skills, tests in CRT can be constructed in open-ended questions or tasks that require the students to use their higher-level cognitive skills, including critical thinking skills, reasoning, analysis, problem-solving, inference, and even interpretation. Kinds of questions that focus on memorization and factual recall such as multiple-choice questions should be avoided since they do not stimulate students' creativity to employ what they have already learned to solve problems or write a critical analysis about an issue. For example, in a vocabulary class, instead of using a matching task to test the students' vocabulary mastery, lecturers could challenge the students to think deeper by assessing them through a role play in which the students could explore and show the richness of their vocabulary in real-life practice.

\section{CONCLUSIONS}

This study sheds light on the need to develop critical thinking skills intentionally through conscious efforts. Higher education institutions need to redefine their goals so that the development of critical thinking skills can be prioritized, and the desired goals can be achieved. Lecturers can incorporate critical thinking skills in their students by not only asking higher-level questions but also giving explicit instructions during the critical thinking development process. Lecturers are expected to facilitate students in expressing their ideas and arguments through cooperative learning activities such as roleplays, discussions, and debates. Lecturers should also employ experiential learning through project-based learning and evaluate the students' learning using criterion-referenced tests to ensure that the students have understood the materials. By integrating the suggested instructional measures, the educational institutions will begin to produce students with remarkable critical thinking skills consistently, and thus resulting in a fully equipped workforce ready to compete and progress in the Industry 4.0 era.

\section{References}

[1] J. Foutty, "Aspire to Lead in Industry 4.0? Hone Your Soft Skills," Deloitte, 23 January 2019. [Online]. Available: https://deloitte.wsj.com/riskandcompliance/2019/01/23/aspireto-lead-in-industry-4-0-hone-your-soft-skills/. [Accessed 4 July 2019].

[2] K. Durkin, "The Middle Way: East Asian Master's Students' Perceptions of Critical Argumentation in U.K. Universities," Journal of Studies in International Education, vol. 12, no. 1 , pp. 38 - 55, 2007.

[3] K. L. Flores, "Deficient Critical Thinking Skills among College Graduates: Implications for Leadership," Educational Philosophy and Theory, vol. 44, no. 2, pp. 212 - 230, 2010.

[4] E. Al-Dumairi and N. A. Al-Jabari, "Arab EFL Students' Application and Awareness of Critical Thinking in College Writing: A Case Study," Arab World English Journal (AWEJ), vol. 6, no. 4, pp. 419 - 431, 2015.

[5] S. C. Choy and P. S. Oo, "Reflective Thinking and Teaching Practices: A Precursor for Incorporating Critical Thinking into the Classroom?," International Journal of Instruction, vol. 5, no. 1, pp. 167 - 182, 2012.

[6] A. Kearney, "Making Indonesia 4.0," Ministry of Industry of the Republic of Indonesia, 2016.

[7] V. Roblek, M. Meško and A. Krapež, "A Complex View of Industry 4.0," pp. 1 - 11, 2016. 
[8] N. HuanSheng and L. Hong, "Cyber-physical-social-thinking space based science and technology framework for the Internet of Things," Science China Information Sciences, vol. 58, pp. 1 - 19, 2015.

[9] M. Fahim and M. B. Bagheri, "Fostering Critical Thinking through Socrates' Questioning in Iranian Language Institutes," Journal of Language Teaching and Research, vol. 3, no. 6, pp. 1122 - 1127, 2012.

[10] H. Sahamid, "Developing critical thinking through Socratic Questioning: An Action Research Study," International Journal of Education \& Literacy Studies, vol. 4, no. 3, pp. $62-72,2016$.

[11] R. Paul, "The State of Critical Thinking Today," NEW DIRECTIONS FOR COMMUNITY COLLEGES, pp. 27 - 38, 2005.

[12] O. L. U. Enciso, D. S. U. Enciso and M. d. P. V. Daza, "Critical Thinking and its Importance in Education: Some Reflections," Rastros Rostros, vol. 19, no. 34, pp. 78 88, 2017.

[13] L. S. Behar-Horenstein, "Teaching Critical Thinking Skills In Higher Education: A Review Of The Literature," Journal of College Teaching \& Learning, vol. 8, no. 2, pp. 25 - 42, 2011.

[14] S. B. H. Siegel, "Critical Thinking," in The Blackwell Guide to the Philosophy of Education, Oxford, UK, Blackwell Publishers, 2007, p. 181-193.

[15] X. Wang and H. Zheng, "Reasoning Critical Thinking: Is It Born or Made?," Theory and Practice in Language Studies, vol. 6, no. 6, pp. 1323 - 1331, 2016.

[16] R. J. Sternberg, H. L. R. III and D. F. Halpern, Critical Thinking in Psychology, New York: Cambridge University Press, 2006.

[17] R. H. Ennis, "Critical Thinking Across the Curriculum: The Wisdom CTAC Program," Inquiry: Critical Thinking Across the Disciplines, vol. 28, no. 2, pp. 25 - 45, 2013.

[18] C. A. Barnes, "Critical Thinking Revisited: Its Past, Present, and Future," New Directions for Community Colleges, vol. 2005, no. 130, pp. 5 - 13, 2005.

[19] N. Noddings, "What Does It Mean to Educate the Whole Child?," Educational Leadership, vol. 63, no. 1, pp. 8 - 13, 2005.

[20] T. v. Gelder, "Teaching Critical Thinking," College Training, vol. 53, no. 1, pp. 41 - 46, 2005.

[21] R. Pithers and R. Soden, "Critical thinking in education: a review," Educational Research, vol. 42, no. 3, pp. 237 - 249, 2000.

[22] E. Chapman and M. O'Neill, "Defining and Assessing Generic Competencies in Australian Universities: Ongoing Challenges," Education Research and Perspectives, vol. 37, no. 1, pp. 105 - 123, 2010.

[23] T. a. H. E. MInistry of Research, "http://kopertis3.or.id," 2015. [Online]. Available: http://kopertis3.or.id/v2/wp-content/uploads/PERMENRISTEKDIKTI-NOMOR-44TAHUN-2015-TENTANG-SNPT-SALINAN.pdf. [Accessed 29 July 2019].

[24] A. M. Amin and R. Adiansyah, "LECTURERS' PERCEPTION ON STUDENTS' CRITICAL THINKING SKILLS DEVELOPMENT AND PROBLEMS FACED BY STUDENTS IN DEVELOPING THEIR CRITICAL THINKING SKILLS," Indonesian Journal of Biology Education, vol. 4, no. 1, pp. 1 - 10, 2018. 
[25] C. L. Mbato, "Indonesian EFL Learners' Critical Thinking in Reading: Bridging the Gap between Declarative, Procedural and Conditional Knowledge," Humaniora, vol. 31, no. 1, pp. 92 - 101, 2019.

[26] G. Manshaee, T. M. Dastnaee, A. Seidi and A. Davoodi, "Comparison of Critical Thinking in Students Interested and Uninterested in Learning a Second Language," Theory and Practice in Language Studies, vol. 4, no. 4, pp. 792 - 799, 2014.

[27] X. Zhang, "Developing College EFL Writers' Critical Thinking Skills Through Online Resources: A Case Study," Sage Publication, pp. 1 - 12, 2018.

[28] J. J. Pikkert and L. Foster, "CRITICAL THINKING SKILLS AMONG THIRD YEAR INDONESIAN ENGLISH STUDENTS," RELC Journal, vol. 27, no. 2, pp. 56 - 64, 1996.

[29] R. N. Indah and A. W. Kusuma, "Factors Affecting The Development of Critical Thinking of Indonesian Learners of English Language," IOSR Journal Of Humanities And Social Science, vol. 21, no. 6, pp. 86 - 94, 2016.

[30] S. Shirkhani and M. Fahim, "Enhancing critical thinking in foreign language learners," in International Conference on Education and Educational Psychology, Istanbul, 2011.

[31] P. C. Abrami, R. M. Bernard, E. Borokhovski, A. Wade, M. A. Surkes, R. Tamim and D. Zhang, "Instructional Interventions Affecting Critical Thinking Skills and Dispositions: A Stage 1 Meta-Analysis," Review of Educational Research, vol. 78, no. 4, pp. 1102 1134, 2008.

[32] D. A. Bensley and R. A.Spero, "Improving critical thinking skills and metacognitive monitoring through direct infusion," Thinking Skills and Creativity, vol. 12, pp. 55 - 68, 2014.

[33] S. Egege and S. Kutieleh, "Critical Thinking: Teaching Foreign Notions to Foreign Students," International Education Journal, vol. 4, no. 4, pp. 75 - 85, 2004.

[34] M. Mahmud, "Questioning Powers of the Students in the Class," Journal of Language Teaching and Research, vol. 6, no. 1, pp. 111 - 116, 2015.

[35] M. Wongdaeng and S. Hajihama, "Perceptions of Project- Based Learning on Promoting 21st Century Skills and Learning Motivation in a Thai EFL setting," Journal for the Study of English Linguistics, vol. 13, no. 2, pp. 158 - 190, 2018.

[36] S. Grant, "Implementing project-based language teaching in an Asian context: a university EAP writing course case study from Macau," Asian-Pacific Journal of Second and Foreign Language Education, vol. 2, no. 4, pp. 1 - 13, 2017.

[37] F. W. English, "The Unintended Consequences of a Standardized Knowledge Base in Advancing Educational Leadership Preparation," Educational Administration Quarterly, pp. 461 - 472, 1 August 2006.

[38] A. J. Grondin, "Effectiveness of the Socratic Method: A Comparative Analysis of the Historical and Modern Invocations of an Educational Method," Honors College, South Carolina, 2018.

[39] Hart Research Associates, "Learning and assessment: Trends in undergraduate education," Association of American Colleges \& Universities , Washington, 2009.

[40] H. Lasi and H.-G. Kemper, "Industry 4.0," Business \& Information Systems Engineering, vol. 6, no. 4, pp. 239 - 242, 2014.

[41] M. Lipman, "Criteria and Judgment in Critical Thinking," Inquiry: Critical Thinking 
Across the Disciplines, vol. 9, no. 4, pp. 3 - 4, 1992.

[42] M. Brady, "Cover the material - Or teach students to think?," Educational leadership, vol. 65, no. 5, pp. 64 - 67, 2008. 